\title{
The Use of Video Project Assignment (VPA) to Enhance Students' Achievement in Communicative English Subject
}

\author{
https://doi.org/10.3991/ijet.v16i23.27447
}

\author{
Kamarul Aina binti Mohamed ${ }^{1}$, Norasykin Mohd Zaid²(凶), Nor Hasniza Ibrahim², \\ Abdul Halim Abdullah², Johari Surif ${ }^{2}$, Ainun Juhariah Hussin ${ }^{1}$ \\ ${ }^{1}$ Politeknik Ibrahim Sultan, Johor, Malaysia \\ ${ }^{2}$ Universiti Teknologi Malaysia, Johor, Malaysia \\ norasykinautm.my
}

\begin{abstract}
Speaking skills is a crucial element which all students in Malaysian polytechnic should master. The new English syllabus introduced in Polytechnic is aimed at building confidence and fluency in English for students as well as enabling them to function effectively at the workplace. Majority of the Communicative English assessment requires students to communicate in English either as individuals or in groups, but many students are still reluctant to speak in front of the classroom and have a very low level of confidence. Thus, Video Project Assignment (VPA) is implemented to boost the achievement of students in the field of Communicative English. The aims of this study are 1) to analyse the student's perception on the use of Video Project Assignment (VPA) in Communicative English subject, 2) to examine students' engagement level towards the use of Video Project Assignment (VPA) based on emotional engagement and cognitive engagement and 3) to identify students' achievement in DUE3012 Communicative English 2 subject. A set of questionnaire was used to gather data from thirty-three respondents from one of the polytechnics in Johor. Descriptive analysis technique was used to analyzed the data gathered from questionnaire. Result of the study indicates that by generating Video Project Assignment (VPA), students demonstrate positive perception, engagement, and achievement. This study also provides the students, lecturers, and potential researcher with a good inference.
\end{abstract}

Keywords—video project assignment, communicative English, emotional engagement, cognitive engagement, students' achievement

\section{Introduction}

In Malaysian Polytechnic, speaking ability is a crucial element that should be mastered by all the students. Hence, Communicative English subject has been introduced in 2010 for the current English Syllabus in polytechnic. According to [13] the new Communicative English Syllabus is designed to develop students' communicative competence in a variety of social interaction and authentic situation. The general aims of 
Polytechnic's Communicative English syllabus are to develop the confidence and fluency of students in English as well as enable them to function effectively at the workplace.

Communicative English is a compulsory subject matter for all Polytechnic students except those undergoing industrial training. All polytechnic students are compulsory to pass their English course as a basic requirement for graduation. The grading system for English subject is determined by students' accumulative marks both in spoken and written assignments, quizzes, listening task, and the final test. Since English subject is based on on-going assessment mode, students could have the opportunity to improve their marks in any of the assessment throughout the semester.

Speaking plays an important part in the polytechnic language learning process. Most of the assessment in the context of Communicative English allows students to interact either as individuals or in groups in English. Speaking evaluation is also viewed as a nightmare for students, as most of the lecturers have often used the same strategy, namely physical presentation, or role play inside the class. Some English lecturers waste their time pressuring their students to speak in the classroom and not providing students with another medium outside of the classroom to conduct or complete their language evaluation. As a result, the students struggled to perform well and earned less scores for their assessment.

Many students feel anxious about talking in front of the classroom and have a very low level of confidence. When speaking outside the classroom, they tend to improvise their imagination, thinking, belief and creativity. Based on this situation, the English lecturer needs to build another platform to address the issues in which students will be more involved and inspired to take part in any speaking activities. Nowadays, with the introduction of technology into the education system, many approaches can be introduced to develop the speaking skills among students.

Video Project Assignment (VPA) is one of the most successful solutions to this issue. This is because it has improved the depth of cognitive development and motivation of the students by doing the Video Project Assignment (VPA). When the students are inspired, they can slowly improve their speaking skills. It is hoped that incorporation of the Video Project Assignment (VPA) in the English language evaluation would enhance students ' achievement in Communicative English subject.

\section{Literature review}

\subsection{Constructivism approach in English language classroom}

Constructivism approach helps students learn better by actively participate and relate the experience they gained with the existing knowledge that they have. Constructivism technique also could be a great tool to help English language learner to be more successful in the classroom. The study conducted by [12] stated that social constructivism emphasizes that learning take place through interactions with other students, teachers, 
and the world at large. Meanwhile, the study on the interaction of constructivism classroom in Malaysian ESL setting found that the approach gives positive impact on relationship between students and students/teacher within the classroom.

\subsection{Video to improve speaking skills}

Video can be a very useful tool for language learning. The major advantage of using video is providing the sample of real-life communication. [17] stated that employing video materials in a classroom can boost students' motivation to learn since it can expose them to a wide variety of situations that can help them realize similar situations in real life. [10] stated that the study on the use of video in English classroom in Norwegian Lower Secondary School revealed that there is improvement in student's communicative skills while using video. Besides that, [1] revealed that the application of video clips has improve young learner speaking performance. Meanwhile, [4] also stated that video blogging has improve speaking skills among students.

\subsection{Students' perceptions on creating video}

A study conducted by [11] found that students are motivated to learn English by producing Video Project Assignment. This claim can also be supported by similar research done by [11] where the finding reveal that students were motivated to learn English and enjoyed it. [2] also claim that creating video seems to be interesting and motivating the students to speak fluently. Besides that, [2] claimed that video project creates self-learning and self-evaluation for the students and makes them motivated to improve their speaking skills. [15] in her study revealed that video project able to draw students' creativity although there was some hesitation to produce it due to lack of experience and limited skills in movie making and editing. [11] in their study claim that students were enjoy while doing their video project.

Table 1. Studies on Students' Perception on the Use of Video

\begin{tabular}{|l|l|l|}
\hline No & \multicolumn{1}{|c|}{ Researcher } & \multicolumn{1}{c|}{ Finding } \\
\hline 1 & $\begin{array}{l}\text { Mohamad Ali, Afiza and } \\
\text { Jabar, Norina (2016) }\end{array}$ & $\begin{array}{l}\text { In general, students seem motivated and enjoy the process of creating cul- } \\
\text { tural Video Project Assignment. The findings reveal that students' percep- } \\
\text { tion towards using video was positive and they were motivated to learn } \\
\text { English }\end{array}$ \\
\hline 2 & $\begin{array}{l}\text { Anida and Andi Patmasari, } \\
(2018)\end{array}$ & $\begin{array}{l}\text { The findings show that creating video has many advantages in engaging } \\
\text { the students to speak English. Creating video seems to be interesting and } \\
\text { motivating the students to speak fluently. It creates self-learning and self- } \\
\text { evaluation for the students and makes them motivated to improve their } \\
\text { speaking skills. }\end{array}$ \\
\hline 3 & Ting, Ng. (2013) & $\begin{array}{l}\text { In general, students show positive perception and excited to produce the } \\
\text { video project although there were some hesitations due to lack of experi- } \\
\text { ence and limited skills in movie making and editing but the project basi- } \\
\text { cally able to appeal students' creativity }\end{array}$ \\
\hline
\end{tabular}


Motivation. A study conducted by [11] found that students are motivated to learn English by producing Video Project Assignment. This claim can also be supported by similar research done by [11] where the finding reveal that students were motivated to learn English and enjoyed it. [2] also claim that creating video seems to be interesting and motivating the students to speak fluently.

Speaking ability. According to [2] video project creates self-learning and self-evaluation for the students and makes them motivated to improve their speaking skills. [11] in her study also found that the video project helped students to train their speaking skills.

Learning experiences. According to [15] video project able to draw students' creativity although there was some hesitation in order to produce it due to lack of experience and limited skills in movie making and editing. [11] in their study claim that students were enjoy while doing their video.

\subsection{Students' engagement on the use of video}

Integrating the technology in language classroom is beneficial especially to the student engagement. Many studies have shown on the advantages of using technology in the classroom. Technology can be used as a tool for creating educational projects to engage students in critical thinking and problem solving. Table 2 shows some related studies regarding students' engagement towards the use of video in language classroom.

Table 2. Studies on Student Engagement towards the use of Video

\begin{tabular}{|l|l|l|l|}
\hline No & \multicolumn{1}{|c|}{ Researcher } & \multicolumn{1}{c|}{$\begin{array}{c}\text { Type of } \\
\text { Engagement }\end{array}$} & \multicolumn{1}{c|}{ Finding } \\
\hline 1. & Jolly Sahni (2019) & $\begin{array}{l}\text { Behavioral Cognitive } \\
\text { Emotional }\end{array}$ & $\begin{array}{l}\text { Generally, the positive results of blended learn- } \\
\text { ing approach give effect to higher student } \\
\text { achievement and improves their engagement. }\end{array}$ \\
\hline 2. & $\begin{array}{l}\text { Denise Stanley and Yi } \\
\text { Zhang (2018) }\end{array}$ & $\begin{array}{l}\text { Behavioral Cognitive } \\
\text { Emotional }\end{array}$ & $\begin{array}{l}\text { video production can improve the level of en- } \\
\text { gagement and learning in online coursework }\end{array}$ \\
\hline 3. & Hyun Gyun Lee (2012) & Cognitive & $\begin{array}{l}\text { Only some participants experienced deep en- } \\
\text { gagement with certain tasks }\end{array}$ \\
\hline 4. & $\begin{array}{l}\text { Abubakar Sani \& Che } \\
\text { Noraini Hashim (2016) }\end{array}$ & Cognitive & $\begin{array}{l}\text { The finding reveals that deep engagement is } \\
\text { more linked with male students while shallow } \\
\text { engagement is related with female students. }\end{array}$ \\
\hline 5. & $\begin{array}{l}\text { Siti Zuraidah Osman \& } \\
\text { Rozinah Jamaludin } \\
\text { (2014) }\end{array}$ & $\begin{array}{l}\text { Behavioral Cognitive } \\
\text { Emotional Agentic }\end{array}$ & $\begin{array}{l}\text { The study found that student engagement from } \\
\text { the aspect of behavioral, cognitive, emotional, } \\
\text { and agentic does not have a significant relation- } \\
\text { ship with student achievement. }\end{array}$ \\
\hline
\end{tabular}

Cognitive engagement. A study conducted by [24] found that deep engagement is more linked with male students while shallow engagement is related with female students. Furthermore, in the study conducted by [23] found that student engagement from the aspect of behavioral, cognitive, emotional, and agentic does not have a significant relationship with student achievement.

Emotional engagement. According to [21], the positive results of blended learning approach give effect to higher student achievement and improves their engagement. It 
is supported by [22] who also claimed that video production can improve the level of engagement and learning in online coursework.

\subsection{Communicative English syllabus in Polytechnic}

According to a study conducted by [25], speaking skills has been given a priority in the teaching of English language in polytechnic. The objective of the English Language syllabus in polytechnics is to equip students with required expertise in academic and technical context so that the students can excel in the industries when they leave polytechnics.

\section{Methodology}

This study is about quantitative study which focuses on students' perception and engagement of using Video Project Assignment (VPA) for DUE 3012 Communicative English 2 subject. Based on the research questions of this study, the quantitative research approach was used to evaluate the test.

The sample of this study was the semester three students from Diploma of Hotel Management who are currently enrolled for DUE3012 Communicative English 2 subject in one of the Politeknik in Johor. Thirty-three (33) semester 3 students were selected as the respondent of this study. They have produced eight sample videos related to the topic given for their assessment to produce a video of role-play regarding 'enquiries and complaint' topic.

An online questionnaire developed by the researcher was used to collect the data on students' perception and engagement towards using Video Project Assignment. The online questionnaire was divided into three parts. The first part is about students' demographic information (gender, age and result). The second part containing 12 items questioning the students' perception of the use of Video Project Assignment using 4point Likert scale: 1=Strongly Disagree, 2=Disagree, 3=Agree, 4=Strongly Agree. While the last part of the questionnaire also containing another 10 items eliciting the students' emotional and cognitive engagement. 4-point Likert scale is used to get specific responses from the respondents.

A pilot study was conducted to obtain validity and reliability of items in the questionnaire. Reliability test for the instrument is also conducted to ensure the item's consistency. The internal consistency (Cronbach Alpha) approach was employed to establish the reliability of the instruments. From the results, the alpha values for the perception and engagement instruments ranged between 0.822 and 0.847 as shown in Table 3.

Table 3. Reliability of Instrument

\begin{tabular}{|l|c|c|}
\hline \multirow{2}{*}{\multicolumn{1}{|c|}{ Instrument }} & \multicolumn{2}{|c|}{ Reliability Statistics } \\
\cline { 2 - 3 } & Cronbach's Alpha & N of Items \\
\hline Perception (Part B) & 0.847 & 10 \\
\hline Engagement (Part C) & 0.822 & 10 \\
\hline
\end{tabular}




\section{Data analysis}

The descriptive analysis was conducted by using Statistical Package for the Social Sciences (SPSS) version 22 software and was describe in detail. In this research, the researchers use descriptive analysis to investigate students' perception and students' engagement on the use of Video Project Assignment while quantitative research analysis was used to identify the frequency and percentage of students' achievement according to grade.

Table 4 shows the level of agreement according to the score value for each item. Items which have value from 1.00 to 1.75 shows a very low agreement level. Value between 1.76 to 2.50 is considered as low level while value from 2.51 to 3.25 show high agreement level. Lastly, items with value from 3.26 to 4.00 is considered has achieve very high agreement level.

Table 4. Level of Agreement based on Score Value

\begin{tabular}{|ll|c|}
\hline & Score Value & Level of Agreement \\
\hline 3.26 & -4.00 & Very High \\
\hline 2.51 & -3.25 & High \\
\hline 1.76 & -2.50 & Low \\
\hline 1.00 & -1.75 & Very Low \\
\hline
\end{tabular}

\section{$5 \quad$ Research finding}

Based on the data gathered, the findings were discussed in order to identify students' perception and students' engagement on the use of Video Project Assignment as well as their achievement in Communicative English subject.

\subsection{Students' perception on motivation construct}

In this construct, students had a very high levels of positive perceptions towards the use of Video Project Assignment. Items which are "I am motivated to speak English better with Video Project Assignment", "I am motivated to give my best effort in this Video Project Assignment", "I am motivated to complete this video project by avoiding mistake while speaking" and "I really enjoyed the whole video production process in order to produce the best video script" received the highest score $(\mathrm{M}=3.27)$ respectively. 
Table 5. Students Perception on Motivation Construct

\begin{tabular}{|l|l|c|c|c|c|c|c|c|}
\hline No & \multicolumn{1}{|c|}{ Statement } & SD & D & A & SA & Mean & SD & Level \\
\hline 1 & $\begin{array}{l}\text { I am motivated to speak English better with Video Project } \\
\text { Assignment }\end{array}$ & 0 & $\begin{array}{c}24 \\
72.7 \%\end{array}$ & $\begin{array}{c}9 \\
27.3 \%\end{array}$ & 3.27 & .452 & $\begin{array}{c}\text { Very } \\
\text { High }\end{array}$ \\
\hline 2 & $\begin{array}{l}\text { I am motivated to give my best effort in this video project } \\
\text { assignment }\end{array}$ & $\begin{array}{c}1 \\
3.0\end{array}$ & $\begin{array}{c}22 \\
66.7 \%\end{array}$ & $\begin{array}{c}10 \\
30.3\end{array}$ & 3.27 & .516 & $\begin{array}{l}\text { Very } \\
\text { High }\end{array}$ \\
\hline 3 & $\begin{array}{l}\text { I am motivated to complete this video project by avoiding } \\
\text { mistake while speaking }\end{array}$ & $\begin{array}{c}1 \\
3\end{array}$ & $\begin{array}{c}23 \\
69.7 \%\end{array}$ & $\begin{array}{c}27.3 \\
27.27\end{array}$ & .516 & $\begin{array}{l}\text { Very } \\
\text { High }\end{array}$ \\
\hline 4 & $\begin{array}{l}\text { I really enjoyed the whole video production process in or- } \\
\text { der to produce the best video script }\end{array}$ & 0 & $\begin{array}{c}23 \\
69.7 \%\end{array}$ & $\begin{array}{c}10 \\
30.3 \%\end{array}$ & 3.27 & .452 & $\begin{array}{l}\text { Very } \\
\text { High }\end{array}$ \\
\hline
\end{tabular}

\subsection{Students' perception on speaking ability construct}

In this construct, item 7 received the highest score $(\mathrm{M}=3.42)$ : Video project assignment helps me to improve my confidence to speak English. The second highest score is item $6(\mathrm{M}=3.30)$ : Video project assignment helps to improve my speaking ability. The third highest score is item $5(\mathrm{M}=3.15)$ : Video project assignment is effective to encourage me using English outside the classroom and the last one is item 8: My fluency in English speaking improve because of this video project assignment $(\mathrm{M}=3.03)$.

Table 6. Students Perception on Speaking Ability Construct

\begin{tabular}{|l|l|c|c|c|c|c|c|c|}
\hline No & \multicolumn{1}{|c|}{ Item } & SD & D & A & SA & Mean & SD & Level \\
\hline 5 & $\begin{array}{l}\text { Video project assignment is effective to encourage me } \\
\text { using English outside the Classroom }\end{array}$ & $\begin{array}{c}4 \\
12.1 \%\end{array}$ & $\begin{array}{c}20 \\
60.6 \%\end{array}$ & $\begin{array}{c}9 \\
27.3 \%\end{array}$ & 3.15 & .618 & High \\
\hline 6 & $\begin{array}{l}\text { Video project assignment helps to improve my speak- } \\
\text { ing ability. }\end{array}$ & 0 & 0 & $\begin{array}{c}23 \\
69.7 \%\end{array}$ & $\begin{array}{c}10 \\
30.3 \%\end{array}$ & 3.30 & .466 & $\begin{array}{c}\text { Very } \\
\text { High }\end{array}$ \\
\hline 7 & $\begin{array}{l}\text { Video project assignment helps me to improve my } \\
\text { confidence to speak English }\end{array}$ & 0 & 0 & $\begin{array}{c}19 \\
57.6\end{array}$ & $\begin{array}{c}14 \\
42.4\end{array}$ & 3.42 & .501 & $\begin{array}{c}\text { Very } \\
\text { High }\end{array}$ \\
\hline 8 & $\begin{array}{l}\text { My fluency in English speaking improves because of } \\
\text { this video project assignment. }\end{array}$ & 0 & $\begin{array}{c}5 \\
15.2 \%\end{array}$ & $\begin{array}{c}22 \\
66.7 \%\end{array}$ & $\begin{array}{c}6 \\
18.2 \%\end{array}$ & 3.03 & .585 & High \\
\hline
\end{tabular}

\subsection{Students' perception on learning experiences construct}

For this construct, items 11 and 12 received the highest score $(M=3.27)$ : This video project assignment helps me to be more confident in front of camera and video project assignment enable me to be more creative. The second highest score is item $9(M=3.12)$ : I feel more comfortable learning English by creating video project assignment followed by item $10(\mathrm{M}=3.06)$ : Video project assignment is more enjoyable than traditional classroom learning. 
Table 7. Students' Perception on Learning Experiences Construct

\begin{tabular}{|l|l|c|c|c|c|c|c|c|}
\hline No & \multicolumn{1}{|c|}{ Item } & SD & $\mathbf{D}$ & $\mathbf{A}$ & $\mathbf{S A}$ & Mean & SD & Level \\
\hline 9 & $\begin{array}{l}\text { I feel more comfortable learning English by creating } \\
\text { video project assignment. }\end{array}$ & 0 & $\begin{array}{c}3 \\
9.1 \%\end{array}$ & $\begin{array}{c}23 \\
69.7 \%\end{array}$ & $\begin{array}{c}7 \\
21.2 \%\end{array}$ & 3.12 & .545 & High \\
\hline 10 & $\begin{array}{l}\text { Video project assignment is more enjoyable than tradi- } \\
\text { tional classroom learning. }\end{array}$ & $\begin{array}{c}7 \\
21.2 \%\end{array}$ & $\begin{array}{c}17 \\
51.5 \%\end{array}$ & $\begin{array}{c}9 \\
27.3 \%\end{array}$ & 3.06 & .704 & High \\
\hline 11 & $\begin{array}{l}\text { This video project assignment helps me to be more confi- } \\
\text { dent in front of camera. }\end{array}$ & $\begin{array}{c}4 \\
12.1 \%\end{array}$ & $\begin{array}{c}16 \\
48.5 \%\end{array}$ & $\begin{array}{c}13 \\
39.4 \%\end{array}$ & 3.27 & .674 & $\begin{array}{l}\text { Very } \\
\text { High }\end{array}$ \\
\hline 12 & Video project assignment enable me to be more creative & 0 & $\begin{array}{c}2 \\
6.1 \%\end{array}$ & $\begin{array}{c}20 \\
60.6 \%\end{array}$ & $\begin{array}{c}11 \\
33.3 \%\end{array}$ & 3.27 & .574 & $\begin{array}{l}\text { Very } \\
\text { High }\end{array}$ \\
\hline
\end{tabular}

\subsection{Students' emotional engagement}

The emotional engagement has been analysed using 5 elements as shown in Table 8 . The frequency and the percentage of each element were measured and shown. The findings revealed that students really like to participate in this assignment (72.7\%). Students really enjoy doing Video Project Assignment (66.7\%) and they also feel that this assignment is very interesting $(66.7 \%)$.

Table 8. Students Emotional Engagement

\begin{tabular}{|l|l|c|c|c|c|}
\hline No & \multicolumn{1}{|c|}{ Item } & SD & D & A & SA \\
\hline 1 & I really enjoy doing Video Project Assignment & 0 & $3(9.1 \%)$ & $22(66.7 \%)$ & $8(24.2 \%)$ \\
\hline 2. & I really like to participate in this assignment & 0 & $1(3.0 \%)$ & $24(72.7 \%)$ & $8(24.2 \%)$ \\
\hline 3. & I can express my emotion freely while completing this assignment. & 0 & $5(15.2 \%)$ & $20(60.6 \%)$ & $8(24.2 \%)$ \\
\hline 4. & This assignment helps to overcome my anxiety. & 0 & $1(3.0 \%)$ & $19(57.6 \%)$ & $13(39.4 \%)$ \\
\hline 5. & I feel that this assignment is very interesting & 0 & $2(6.1 \%)$ & $22(66.7 \%)$ & $9(27.3 \%)$ \\
\hline
\end{tabular}

\subsection{Students' cognitive engagement}

The result for emotional and cognitive engagement among gender were obtained using Mean and Std. Deviation. In obtaining the result, mean and std. deviation for the sample and the population were compared in drawing conclusion. Table 9 presents the degree of emotional and cognitive engagement among gender. Male students show the highest score $(M=3.37)$ for emotional engagement as well as cognitive engagement $(\mathrm{M}=3.31)$. While female students $(\mathrm{M}=3.16)$ for emotional engagement and $(\mathrm{M}=3.19)$ for cognitive engagement.

Table 9. Students' Cognitive Engagement

\begin{tabular}{|l|l|c|c|c|c|}
\hline No & \multicolumn{1}{|c|}{ Item } & SD & D & A & SA \\
\hline 1. & I concentrate well while doing Video Project Assignment & 0 & $6(18.2 \%)$ & $19(57.6 \%)$ & $8(24.2 \%)$ \\
\hline 2. & I learn a lot of new things while completing the video & 0 & 0 & $22(66.7 \%)$ & $11(33.3 \%)$ \\
\hline 3. & This assignment encourages my creative thinking skills & 0 & $1(3.0 \%)$ & $21(63.6 \%)$ & $11(33.3 \%)$ \\
\hline 4. & I can relate this activity with my prior knowledge & 0 & 0 & $26(78.8 \%)$ & $7(21.2 \%)$ \\
\hline 5. & I am excited to have similar activity like this in next semester. & 0 & $3(9.1 \%)$ & $21(63.6 \%)$ & $9(27.3 \%)$ \\
\hline
\end{tabular}




\subsection{Student's achievement}

Table 10 reveals the breakdown result according to grade. Based on the result, $78.8 \%$ (26) students managed to get grade A for their communicative English 2 subject and another $21.2 \%(7)$ able to get grade B.

Table 10.

Breakdown Result based on Grade

\begin{tabular}{|l|c|c|}
\hline \multicolumn{1}{|c|}{ Result } & Frequency & Percentage \\
\hline A & 26 & 78.8 \\
\hline B & 7 & 21.2 \\
\hline Total & 33 & 100 \\
\hline
\end{tabular}

Correlation tests were conducted to identify whether there was a significant correlation between students' perception on the use of Video Project Assignment with their engagement. Table 11 reveals that correlation between students' perception and students' engagement was significant $(r=0.782)$. Therefore, it can be concluded that there is a positive and high relationship between the variables studied.

Table 11. Correlations Analysis

\begin{tabular}{|c|c|c|c|}
\hline & & Perception & Engagement \\
\hline \multirow{3}{*}{ Perception } & Pearson Correlation & 1 & $.782^{* *}$ \\
\hline & Sig. (2-tailed) & & .000 \\
\hline & $\mathrm{N}$ & 33 & 33 \\
\hline \multirow{3}{*}{ Engagement } & Pearson Correlation & $.782^{* *}$ & 1 \\
\hline & Sig. (2-tailed) & .000 & \\
\hline & $\mathrm{N}$ & 33 & 33 \\
\hline
\end{tabular}

**. Correlation is significant at the 0.01 level (2-tailed).

\section{Feedback}

\subsection{Students' perception on speaking ability construct}

The result of the analysis in this research question can be summarized into three main categories which are motivation, speaking ability and learning experiences.

Motivation. This construct shows a very high level of perception from students towards the use of Video Project Assignment with the mean of 3.72. Majority of the students believe that they are motivated to speak English better with the use of Video Project Assignment. This is in line with [11] and [2] who also claimed that creating video seems to be interesting and motivating the students to speak fluently. This situation happens because while producing a video project, it created self-learning and selfevaluation for the students where they can record the video, watch it and freely improve their mistake by themselves and their group members. 
Speaking ability. Another construct in students' perception analysis is speaking ability. In this construct, majority of the students agree with the statements that video project assignment encourage them to use English outside the classroom, helps to improve their speaking ability and improve their confidence to speak English fluently. This corresponds to studies done by [2]. It also supported the problem statement where most of the students feel nervous when they are required to speak in front of other, but they perform very well while using another presentation approach.

Learning experiences. Learning experiences is the last construct under students' perception analysis. Based on the findings, majority of students agree that they feel more comfortable learning English by creating video project assignment. Besides that, they are also enjoying themselves while producing video project assignment. They also believe that the video project assignment enables them to be more confident and creative. This is in line with [11] and [15] who found that students were enjoy with the use of video project as a tool in their language learning process.

\subsection{Students' engagement on the use of video project assignment (VPA)}

To identify the engagement towards the use of video project assignment, students were asked to answer ten questions regarding emotional and cognitive engagement.

Emotional engagement. Majority of the students indicated that they really enjoy and like to participate in the video project assignment because they can express their emotion freely and overcome their anxiety. Besides that, they also found that this assignment is very interesting. This is corresponding to [22] who claimed that video production can improve the level of engagement.

Cognitive Engagement. The results of the data indicated that majority of the students concentrate well while doing the video. They also learn a lot of new things while completing the video and this assignment also encourages their creative thinking skills. Students also can relate this activity with their prior knowledge and excited to have similar task again in the future. This in in line with constructivism approach which helps students to learn better by actively participate and relate the experience they gained with the existing knowledge that they have.

Student's achievement. The findings on the students' achievement revealed that majority of the students (78.8\%) managed to achieved grade A for their Communicative English subject. This finding supported the study conducted by [21] which stated that positive results of blended learning approach give effect to students' achievement and improves their engagement. The finding also reveals that male students perform better in the subject compared to female students. This might be due to the number of male students which is lesser than female students in this study.

\section{$7 \quad$ Summary}

This study determined the students' perception on the use of Video Project Assignment, students' engagement towards the use of Video Project Assignment and students' achievement in Communicative English subject. The students' perception, engagement 
and achievement were assessed using a set of questionnaires adapted from Henry Gina (2012) and Reeve (2013). The result demonstrated that Video Project Assignment (VPA) provides positive feedback on students' perception as well as engagement.

The findings of the study also give positive impact to the students, lecturer as well as future researcher. Lecturers can use this alternative assessment method to reduce their workload in evaluating students' assessment while future researcher might come out with bigger scale research regarding the use of Video Project Assignment (VPA).

\section{$8 \quad$ Limitations and future studies}

This research is expected to inspire more researchers to conduct another research regarding the use of Video Project Assignment (VPA) in bigger scale in the future. Besides that, a study regarding the relationship between students' engagement and students' achievement also can be conducted by other researcher to find out the level of engagements can give effect to students' achievement. Since the present study focusing on semester 3 students from Diploma in Hotel Management course, another researcher might come out with a research in different population and sample who have different education level, ages and discipline. It is also very important for the future researcher to modify the approach use in this study to get greater result and finding.

\section{Acknowledgement}

The authors would like to thank Mohamo Resources and Universiti Technologi Malaysia for their support in making this project possible. This work was supported by the Contract Grant Scheme (R.J130000.7653.4C436) initiated by Mohamo Resources.

\section{References}

[1] A. Muslem, F. Mustafa, B.Usman, \& A.Rahman, "The application of video clips with small group and individual activities to improve young learners' speaking performance." Teaching English with Technology, 17, 25-37. [online] Available: https://files.eric.ed.gov/ fulltext/EJ1159095.pdf [Accessed Dec.3,2020].

[2] A. Anida \& A.Patmasari, "The Students' Perceptions of Creating Videos to Engage Them in Speaking." ESL Juournal on Interdiscipnary Studies on Humanities, 1 (3), 272-287. [online].https://doi.org/10.34050/els-jish.v1i3.4757 [Accessed Oct. 30. 2020].

[3] A. Aksel, \& G.K. Fatma, "Video Project Assignments and Their Effectiveness of Foreign Language Learning. Social and Behavioral Sciences journal 141, 319-324. [online] Available: https://doi.org/10.1016/j.sbspro.2014.05.055 Accessed Nov.13, 2021].

[4] V. D. Balakrishnan, \& F. Puteh, "Blending face-to-face communication and video blogging in acquiring public speaking skills". Journal of Creative Practices in Language Learning and Teaching (CPLT), 2 (1), 64-72.[online] Available: https://api.semanticscholar.org/CorpusID:222526876 [Accessed Nov.20, 2020] 
Paper-The Use of Video Project Assignment (VPA) to Enhance Students' Achievement in...

[5] L. C. Dass, \& P. Ferguson, "Interaction in a Constructivist Classroom in a Malaysian Undergraduate ESL Setting” Malaysian Journal of ELT Research, Vol. 8(2), pp. 50-72. [online] Available: https://api.semanticscholar.org/CorpusID:151697221 [Accessed Nov. 24, 2020]

[6] H.Greene, \& C. Crespi, "The value of student created videos in the college classroom-an exploratory study in marketing and accounting” International Journal of Arts \& Sciences, 5(1), 273. [online] Available: https://api.semanticscholar.org/CorpusID:113129550 [Accessed Dec.3, 2021]

[7] P. J. Guo, J. Kim, \& R. Rubin, "How video production affects student engagement: An empirical study of MOOC videos." [online] Available: https://doi.org/10.1145/2556325. 2566239 [Accessed Dec.3, 2020]

[8] Hea Suk Kim, “Using Authentic Video to Improve EFL Students' Listening Comprehension." International Journal of Contents, Vol. 11, No.4. [online] Available: https://doi.org/ 10.5392/ijoc.2015.11.4.015 [Accessed Dec.3, 2020]

[9] C. R. Henrie, L. R. Halverson, \& C. R. Graham, "Measuring student engagement in technology-mediated learning: A review. Computers \& Education," 90, 36-53. [online] Available: https://doi.org/10.1016/j.compedu.2015.09.005 [Accessed Dec.3,2020]

[10] D. Lialikhova, "The use of video in English language teaching: A case study in a Norwegian lower secondary school". [online] Available: https://api.semanticscholar.org/CorpusID:77544672 [Accessed Dec.3, 2020]

[11] Mohamad Ali, Afiza and Jabar, Norina, "Cultural video project assignment (VPA) through the eyes of young ESL learners: a multi-modal vocabulary learning approach." Indonesian Journal of EFL and Linguistics, 1 (2). pp. 157-173. [online] Available: https://doi.org/ 10.21462/ijefll.v1i2.11 [Accessed Dec.3, 2020]

[12] Muna Aljohani, "Principles of "Constructivism" in Foreign Language Teaching." Journal of Literature and Art Studies, January 2017, Vol. 7, No. 1, 97-107. [online] Available: https://doi.org/10.17265/2159-5836/2017.01.013 Accessed Dec.3, 2020]

[13] S. Abdullah, \& F. A. Majid, "English language teaching challenges in Malaysia: Polytechnic lecturers' experience. World Applied Sciences Journal, 28(4), 540-547. [online] Available: https://api.semanticscholar.org/CorpusID:114146718 [Accessed Oct.12, 2020]

[14] Nyaradzo Mvududu1 \& Jennifer Thiel-Burgess, "Constructivism in Practice: The Case for English Language Learner.” International Journal of Education, 4, 108-118. https://doi.org 10.5296/ije.v4i3.2223

[15] Ng. Ting, "Classroom Video Project: An Investigation on Students Perception. Procedia Social and Behavioral Sciences." 90. 441-448. [online] Available: https://doi.org/10.1016/ j.sbspro.2013.07.113 [Accessed Dec.3, 2020]

[16] S.Sumardi, , \& A. N. Wijaya, "Digital Video Project: An Authentic Assessment to Assess Students' Speaking Skills.” Indonesian Journal of EFL and Linguistics, 5(1), 57-72. [online]. Available: https://doi.org/10.21462/ijefl.v5i1.217 [Accessed Dec. 3,2020]

[17] M. Xhemaili, "The Advantages of Using Films to Enhance Student's Reading Skills in the EFL Classroom." Journal of Education and Practice, 4, 62-66. [online]. Available: https://www.iiste.org/Journals/index.php/JEP/article/view/6775 [Accessed Dec. 3,2020]

[18] O. Marlissa, A. Dayana Farzeeha, M. Mahani, M.Z. Norasykin, J. Hanifah, I. Nor Haniza, "Effect of Mobile Augmented Reality (MAR) towards Students' Visualization Skills while Learning Orthographic Projection.” International Journal of Emerging Technologies in Teaching. [online] Available: http://dx.doi.org/10.3991/ijet.v14i20.11463 [Accessed Dec.8, 2020]

[19] M.Z. Norasykin, Y. Fatimah Sarah, A.S. Nurbiha, M.S. Mohd Nihra Haruzuan, H.M. Aede, Desi Rahmatina, "Integration of Peer Instruction in Online Social Network to Enhance 
Paper - The Use of Video Project Assignment (VPA) to Enhance Students' Achievement in...

Higher Order Thinking Skills" International Journal of Emerging Technologies in Teaching. [online] Available: https://doi.org/10.3991/ijim.v12i8.9672 [Accessed Dec. 8, 2020]

[20] S. Hon Mun, A. Abdul Halim, M. Mahani, A. Dayana Farzeeha, J. Nurul Farhana, M.A Zakiah, A.S. Norazrena, A.R. Khairul Anuar, "Active Learning Using Digital Smart Board to Enhance Primary School Students' Learning." International Journal of Emerging Technologies in Teaching. [online] Available: http://dx.doi.org/10.3991/ijim.v13i07.10654 [Accessed Dec. 8, 2020]

[21] S. Jolly, "Does Blended Learning Enhance Students' Engagement". [online] Available: https://doi.org/10.5171/2019.121518 [Accessed Dec. 20, 2020]

[22] D. Stanley \& y. Zhang, "Do Student-Produce Video Enhance Engagement and Learning in Online Environment." [online] Available: https://doi.org/10.24059/olj.v22i2.1367 [Accessed Dec. 20, 2020]

[23] J. Rozinah, M.O. Siti Zuraidah, "A Case Study in Fundamental of Accounting in Malaysian Polytechnic". [online] Available: https://doi.org/10.20448/journal.509/2016.3.1/509.1. 23.31 [Accessed Dec. 25, 2020]

[24] S. Abubakar, "Evaluating the Student's Level of Cognitive Engagement to Achieve English language Curriculum Objectives at International Islamic School,Gombak". [online] Available: https://doi.org/10.9734/air/2016/29456 [Accessed Dec. 25, 2020]

[25] R. Rashidah, E. Mohamed Amin, "Use of Communicative Language Teaching in Malaysian Polytechnic". [online] Available: https://api.semanticscholar.org/CorpusID:208628836 [Accessed Dec.25. 2020]

\section{Authors}

Kamarul Aina Mohamed is a Master's Degree student in School of Education, Faculty of Social Sciences and Humanities, Universiti Teknology Malaysia (UTM). She works as a lecturer at Politeknik Ibrahim Sultan, Johor (email: kamarulaina@pis.edu.my).

Norasykin Mohd Zaid is a senior lecturer at the School of Education, Faculty of Social Sciences and Humanities, Universiti Teknologi Malaysia. She received the degree of Bachelor of Science (Honors) in Computer Science (2000) and the Master's Degree (Educational Technology) (2006) from Universiti Teknologi Malaysia (UTM), Malaysia and the Ph.D. degree from University of Wollongong (UoW), Australia in 2013. She is the Program Coordinator of the Educational Technology Program for Postgraduate Studies since 2018. Her research interests include online education and training, information systems and new media in teaching and learning.

Nor Hasniza Ibrahim is senior lecturer in Department of Educ Science, Mathematics and Multimedia Creative, Faculty of Science Social and Humanities, Universiti Teknologi Malaysia, Johor Bahru, Malaysia, 81310. She received her Bachelor in Biomedical Sciences from Universiti Putra Malaysia, Master's Degree and Doctor of Philosophy in Chemistry Education from Universiti Teknologi Malaysia. Her research interest is regarding science education, chemistry education and STEM education. She now works as senior lecturer in She also currently actively involved in research and programs related to STEM education and indigenous people (email: p-norhaniza (a)utm.my). 
Abdul Halim Abdullah is associate professor in Department of Educ Science, Mathematics and Multimedia Creative, Faculty of Science Social and Humanities, Universiti Teknologi Malaysia. He received his B.Sc. (Edu) and M.Sc. (Edu) degrees in Mathematics Education from Universiti Teknologi Malaysia (UTM). He obtained his PhD degree in Mathematics Education from Universiti Kebangsaan Malaysia (UKM). He has been serving at the School of Education, UTM since 2006. His research areas are geometry thinking, higher order thinking skills (HOTS) in mathematics and technology-aided teaching and learning in mathematics. To date, he has received nine research grants as a Principal Investigator including one from Majlis Amanah Rakyat (MARA), plus 20 grants as a co-investigator. He was also involved as a researcher in a collaborative IRU-MRUN research between the Malaysian Research Universities and Australian Innovative Research Universities.

Johari Surif is associate professor in Department of Educ Science, Mathematics and Multimedia Creative, Faculty of Science Social and Humanities, Universiti Teknologi Malaysia, Johor Bahru, Malaysia, 81310. He received Bachelor in Envi-ronmental Sciences from Universiti Kebangsaan Malaysia, Master's Degree and Doctor of Philosophy in Chemistry Education from Universiti Teknologi Malaysia. His research interest is regarding science education, chemistry education and STEM education. He also currently actively involved in research and programs related to STEM education, community and many more (email: johari_surif@utm.my).

Ainun Juhariah Hussin is currently a lecturer in General Studies Department, Politeknik Ibrahim Sultan Johor. She has more than 15 years' experience in teaching English for Technical Purposes and Communicative English subject.

Article submitted 2021-09-26. Resubmitted 2021-10-28. Final acceptance 2021-10-29. Final version published as submitted by the authors. 